\title{
Measuring Small Business Customer Satisfaction
}

\author{
Henry B. Balfanz, Alma College, USA
}

Laura Lowe, Alma College, USA

\begin{abstract}
Most family owned small businesses are so concerned about keeping the doors open on a daily basis that not a lot of time is spent on researching their customer satisfaction. As well, funds for such marketing research are often limited. Trying to keep personal bias out of such research is difficult. Thanks to the Ultimate Question/Net Promoter Score now there is a simple way to measure customer satisfaction by asking a single question. Can this work for a small dance business in mid-Michigan?
\end{abstract}

Keywords: Customer Satisfaction; Ultimate Question; Marketing; Family Owned Business; Dance

Suggested Courses: Marketing and Society; Cases and Applications in Marketing; Dance Professions

\section{INTRODUCTION}

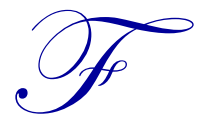
red Reichheld (2003), a Fellow with the consulting firm Bain and Company, published his first article "The One Number You Need to Grow" in the Harvard Business Review (2003). It was welcomed in the business community as a revolutionary way to measure customer satisfaction. The consultant followed up with his book, The Ultimate Question: Driving Good Profits and True Growth (2006) and eventually, The Ultimate Question 2.0; How Net Promoter Companies Thrive in a Customer-Driven World (2011), co-authored with Rob Markey, also of Bain. The concept is simple. You have a one question survey you ask your customers: How likely is it you would recommend this company to a friend or colleague?

In his writings, he uses examples of national companies, such as Enterprise Rent A Car and Charles Schwab and Company who have successfully used The Ultimate Question (also known as the Net Promoter Score) to help grow their businesses (Reichheld, 2006). To this day, the Ultimate Question methodology is used by a number of large national businesses.

Can the concept be used for a small business in a small community with only local customers? Doesn't a small business owner need to know more about their customers' level of satisfaction than what one answer will reveal? These questions were put to the test for a 'ma and pa' dance business, DuHadway Dance Dimensions, a 400 to 450 customer family oriented business in Alma, Michigan, a small community of 9000 people in central Michigan.

\section{WHY ONLY ONE QUESTION?}

There seems to be a lot of dissatisfaction with satisfaction surveys. Reichheld (2006) gives ten reasons why most satisfaction surveys fail. Two reasons he gives get to the heart of the matter. There are 'too many surveys, too many questions.' Who has time to complete a 25 question survey about their experience in a hotel over a weekend? He also points out that 'too many surveys are marketing campaigns in disguise' (pp. 77-83). The business asking for your response is actually trying to see if you have other needs you need fulfilled or they are trying to turn you into a repeat customer. All under the guise of trying to learn your opinion. Most savvy customers see through this ploy right away and refuse to complete the survey on that basis. 


\section{MEET THE ENTREPRENEURS: DUHADWAY DANCE DIMENSIONS}

Jillian Labinski and Rob DuHadway met while students at Central Michigan University in the late 1980s. The native Michiganders married in August 1992. "Rob took an interest in my dance career from the very start, and we've turned out to be very good partners," brags Jillian. At a very young age, she started taking dance lessons, similar to the many students she has today. While at CMU, Jillian was teaching for the Linda Lee Dance Studios in Alma, just 15 miles down Michigan route 127 from CMU.

They purchased the studio where she was teaching in May 1992 from the owner Linda Lee who had been in business for 35 years. Having recently celebrated their $25^{\text {th }}$ year in business, the studio has been a part of the dance scape in mid-Michigan for 60 years. Jillian called every customer (112 students) after buying the business in hopes they wouldn't lose any customers. Her attention to detail and friendly manner led to a seamless transition in the ownership change. In 1994, they bought a studio in nearby Ithaca, and then operated two locations, with membership approaching her then goal of 300 students.

In 2005, the DuHadways opened their new studio in Alma, moving out of their two studios. The new 12,000 square foot studio is centrally located along Alma's main street tucked into the outside corner of a shopping center. This studio is much larger than both of their two previous locations combined. The new facility offers four large dance studios, a spacious lobby area, a full locker room with sinks, showers, and multiple restrooms, a large lounge area with vending machines, convenient parking, and a huge customer service area.

DuHadway Dance Dimensions “... is 100\% about family," according to Jillian. With a staff of 14 dance instructors, she feels she has a strong mentoring influence. She's had well over 100 different dance instructors since 1992. Many of her instructors are also public grade school or college teachers, so they have the insight to understand the importance of working with young children (and parents). She wants her instructors to refer to DuHadway as 'we' not 'they' when talking to others about the studio.

Their goal has always been "fun with a purpose," according to the DuHadway web site www.duhadwaydancedimensions.com. Also, from the website, the DuHadways state, "We've found that our curriculum driven approach not only provides a fun experience for your dancer while she is here, but it lays the groundwork for having even more fun as they advance to higher skill levels without struggling to learn the concepts." It's not just up to the instructors as to what they want to teach or what the student does or doesn't want to learn, they follow a set structure and students are promoted as they learn the program designed by Jillian and her instructors. For example, 'Pre-Ballet One graduates into Pre-Ballet Two'. Each year students at the same level learn a set of skills no matter which teacher they have so that they can continue with the curriculum the following year with a different teacher.

Jillian and Rob are proud of the fact that many of their students have gone onto college to major in Dance. Many have also gone onto professional careers. Many have opened their own studios. They are also proud of their 22-year-old son, Charlie, who teaches five days a week in the studio.

In addition, DuHadway Dance Dimensions fields a competitive team of dancers in the ages 8 to 18 , known as the Elite Dancers.

\section{TARGET MARKET/WHY SO POPULAR?}

Since the dancers can start as young as three years of age, it follows logically that the target market for DuHadway would be their 'Moms', primarily. Perhaps the target market could be defined in a conventional sense as women 2544. The DuHadways estimate the average tuition for a school year full of weekly dance lessons at $\$ 300$, an amount not out of reach for most parents. They are quite accommodating, as they have a payment plan if a parent wishes to pay for her child's classes as she goes.

Dance is a safe, fun, and educational activity for parents to bring their children to. Starting at the age of three, children will learn basic motor skills, for example, balancing on one foot and hopping. Young students also start to gain social skills before starting preschool and begin to learn how to follow directions in a classroom setting. Dance is becoming a popular activity among parents because of the benefits for their children. 


\section{MEASURING LOYALTY-THE NET PROMOTER SCORE}

The DuHadways agree with Fred Reichheld, that customer loyalty is most important.

'Loyalty is the key to profitable growth.' So, writes Reichheld (2006) in the very first chapter of The Ultimate Question. He also writes that there is 'no standard, no reliable metric for [measuring] customer relationships, [so] employees can't be held accountable for them and so overlook their performance' (p. 17). The importance of loyalty is not lost on the DuHadways; it's a priority for them as they know there's plenty of competition ( 8 to 10 studios within a thirty-mile radius of Alma) for the dance dollar.

As Peters \& Waterman (1982, p. 268) quoted organizational theorist Mason Haire in In Search of Excellence, "what gets measured, gets done." By answering the Ultimate Question (how likely is it that you would recommend this company to a friend or colleague?) it becomes possible to create such a metric by producing the Net Promoter Score, also known as NPS.

According to Reichheld (2006), the results of the Ultimate Question gives us three different categories of customers. The Promoters are the customers every business wants more of. They are highly satisfied customers who spread the word that the business is the place to frequent. The Passives sit in the middle but are not big cheerleaders for the business. They are easy to lose to a competitor. Finally, the Detractors, who are not at all satisfied with the business and have no qualms about sharing their unhappiness (p. 19).

He goes on to say, "a growth engine running at perfect efficiency would convert 100 percent of a company's customers into promoters. The worse possible engine would convert 100 percent into detractors." (Reichheld, 2006, p. 19).

To gauge a company's efficiency, it would make sense to take the percentage of customers who are Promoters (P) and subtract the percentage who are Detractors (D) to calculate the NPS.

$$
\mathrm{P}-\mathrm{D}=\mathrm{NPS}
$$

Many firms sputter along at an NPS efficiency of 5 to 10 percent, says Reichheld (2006, p. 20). Even firms at the top of their categories have NPS efficiencies of 50-80 percent. Everyone has room for improvement. It is also interesting to note that businesses that are in the service industries (such as airlines) will tend to have lower scores than those in goods-based businesses (such as motorcycles). Obviously, the DuHadways are in a service-based business.

Since the DuHadways do not have competitors who are engaging in the Ultimate Question research to compare their NPS to, they would be more likely to use the Net Promoter Score as a benchmark and perhaps repeat the survey every year to see if their NPS score grows or declines. There are obvious benefits of using the NPS as a yearly report card.

\section{COMING UP WITH THE RIGHT WORDING}

After some discussion, the DuHadways agreed to use the question, "would you recommend duhadway dance dimensions to your best friend?" A second question was added to the survey, "what is the primary reason for your score?"

The temptation to add the second question was simply too strong. It was felt the question was related; the rules were stretched to help give insight into the reason for the Ultimate Question answer. In addition to that, author Reichheld (2006), in the chapter entitled The Rules of Measurement, gives an okay to asking a second question. He notes that follow-up questions "are purely for diagnostic purposes; they don't affect the [NPS] score itself" (p. 96).

For the purpose of this survey, the DuHadways used direct mail to ask their customers the Ultimate Question. 


\section{THE DESIGN AND THE METHODOLOGY}

A sample of the finished response card sent to current customers can be found in Appendix A. The stamped and preaddressed card was placed inside a pink envelope and mailed to the parent(s) of current students aged 3-12 years. The DuHadways have used pink envelopes in the past for direct mail purposes so the envelope stands out from other mail received on that day.

Also included in the envelope was a carefully worded letter from the DuHadways. Care was taken to make sure that it wasn't a marketing communication, but simply a sincere effort to learn the current customer's opinion. An example of the letter can be found in Appendix B.

The card that the respondent returns features a 0-10 scale with ten being the most likely to recommend DuHadway Dance Dimensions. The author gives a number of reasons as to why they like the 0 to 10 scale. "Customers find that the scale makes intuitive sense, probably because of their experience in school. They quickly grasp that a 10 or 9 corresponds to an A or A-, an 8 or 7 represents the adequate performance of a B or C, and 6 or below is a failing grade." (p. 98).

Exhibit 1. Satisfaction Continuum

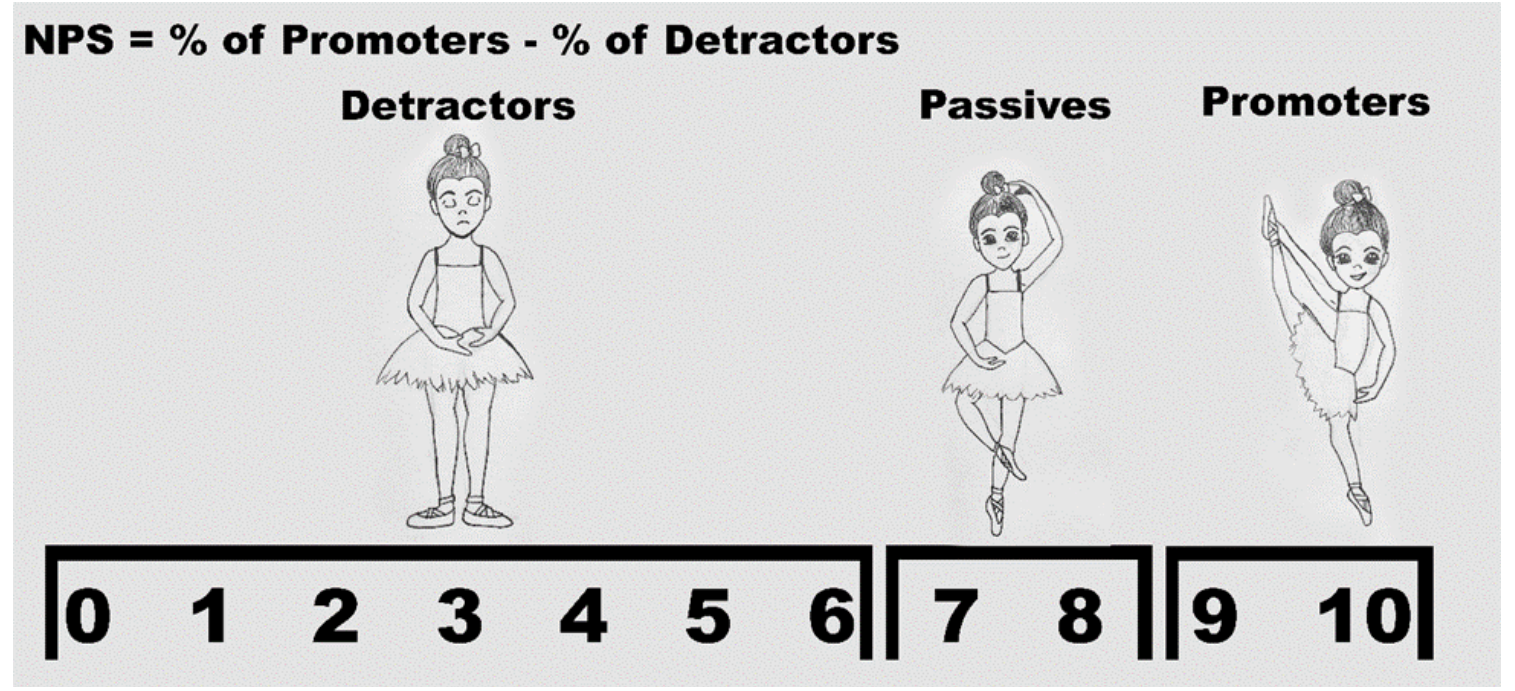

Source: Anissa Keeler

\section{CREATING NET PROMOTER SCORING SCALE}

As stated earlier, the definition of Promoters: "loyal enthusiasts who keep buying from a company and urge their friends to do the same". Only responses that give a score of 9 or 10 are considered to be Promoters. On the other end, you have Detractors. These are the unhappy customers. Scores of 0 to 6 were labeled detractors. In the middle section, you have the Passives, who do not have a strong sense of loyalty and could be at risk of moving their business elsewhere.

Passives are not counted in the equation of P-D = NPS; they are only used in the sample size. For example, a company receives one hundred completed surveys. 80 score the company as 'would strongly recommend' (a 9 or 10) while 10 score the company in the 0 to 6 range. The remaining ten (Passives) score the company as a 7 or 8 . The Net Promoter score in this example:

$$
80 \% \text { PROMOTERS- } 10 \% \text { DETRACTORS }=70 \% \text { NET PROMOTER SCORE }
$$

$(80-10) / 100=70 \%$ NPS 


\section{DUHADWAY DANCE DIMENSIONS NET PROMOTER SCORE RESULTS}

The DuHadways sorted through their database and identified 246 unique families with children aged 3 to 12 who were currently participating in one of their programs. Of the 246 mailed, five were returned for no forwarding address. Therefore, the number of families mailed successfully totaled 241 .

No incentives to respond were offered and the collection and calculating of the responses was completed by the Marketing professor and students of Alma College's Business Administration department. A total of 55 responses were received within a month of the mailing. Of course, as outlined in the letter enclosed with the response form, the responses were anonymous.

The scoring of the responses and actual comments as to why they gave the DuHadways the score they did can be found in Appendix C.

The raw scores show 50 responses of 9 or 10, with 4 responses of 8 , and 1 response of 5 .

Calculating the Net Promoter Score:

$$
\begin{aligned}
& \text { Promoters }(50 / 55=91 \%) \text {-Detractors }(1 / 55=2 \%)=89 \% \text { NET PROMOTER SCORE } \\
& 91 \%-2 \%=89 \%
\end{aligned}
$$

\section{ANALYSIS OF THE NET PROMOTER SCORE}

At first glance, one is impressed with the NPS score of $89 \%$. That's pretty close to perfect and very high for a serviceoriented business dealing with children and parents. One would ask, where is the room for improvement? What needs to be improved? Perhaps an analysis of the comments as to why respondents scored as they did is in order; though in examining those comments, one is hard pressed to find more than just a few negative comments and a spattering of suggested improvements.

What is alarming about the Ultimate Question/NPS survey was the low response rate of only $23 \%$ of the database mailed. Fred Reichheld (2006, p. 101)., in his chapter on measurement, states "A good rule of thumb is this: if your survey response rates are lower than $65 \%$ you are not hearing from enough customers." What would be the reason for a low response rate?

Could it be that parents receiving the pink envelope simply perceived it as an advertisement? Why did customers apparently feel hesitant about answering? Or did they believe it was some sort of marketing ploy, as discussed earlier? Should the DuHadways have used e-mail to try to get a response? Would texting have been more effective? Or hiring an independent firm to call parents at home to get a response?

\section{TO SUMMARIZE}

Though the response rate was disappointing, the NPS and the comments were encouraging and show the DuHadways have built a very good, very family-oriented dance studio.

This initial use of the Ultimate Question/Net Promoter Score gives the DuHadways a base score in order to grow. If the response rate can be improved by choosing one of the alternative ways, the score will have more credibility. The DuHadways should address the few less than positive comments to see if this can improve their score in the future. 


\section{DISCUSSION QUESTIONS}

1) Should the survey be considered a "failure" because of the low response rate? Why or why not?

2) Review the negative comments in Appendix C. If you were the DuHadways, what would be your plan of action regarding these comments?

3) Identify behavior that would build a strong feeling of family in a dance studio.

4) Should the DuHadways consider smaller classes?

5) How would you 'screen' a potential dance instructor?

6) What other ways could the DuHadways measure customer satisfaction?

Educators: Teaching notes provided upon request. (balfanzhb@alma.edu)

\section{AUTHOR BIOGRAPHY}

Henry Balfanz (Contact Author) is an Assistant Professor of Business Administration at Alma College in Alma, Michigan. He also taught Marketing at Bradley University in Peoria, Illinois and Northern Michigan University in Marquette, Michigan, and Vysoka Skola Ekonomicka in Prague, Czech Republic on seven occasions. Prior to teaching, he was an Executive in the broadcast, newspaper, and advertising industries. Balfanz holds a Bachelor of Science in Broadcast Management from Southern Illinois University at Carbondale and a Masters of Business Administration from Bradley University.

Laura Lowe, a graduate of Alma College, class of 2018 in Alma, Michigan, earned her Bachelors of Arts in both Professional Accounting and Dance-graduating Magna Cum Laude with honors. Lowe grew up dancing at DuHadway Dance Dimensions and enjoyed teaching for them while attending college. She had an internship at an accounting firm, which provided entry level accounting skills. Lowe enjoyed dancing and performing with the Alma College Dance Company and Kiltie Dancers during her college years. Post-graduation, Lowe will take the CPA exam and working in the Foreign Direct Investments department at Clayton \& McKervey in Southfield, Michigan.

\section{REFERENCES}

Markey, R. \& Reichheld, F. (2011). The ultimate question 2.0: How net promoter companies thrive in a customer-driven world. Harvard Business School Publishing Corporation.

Peters, T. \& Waterman Jr., R. (1982). In search of excellence. New York: Harper \& Row, Publishers.

Reichheld, F. (2003). The one number you need to grow. The Harvard Business Review, Dec. 2003, hbr.org/2003/12/the-onenumber-you-need-to-grow.

Reichheld, F. (2006). The ultimate question: Driving good profits and true growth. Harvard Business School Publishing Corporation. 


\section{APPENDIX A}

\section{Response Card}

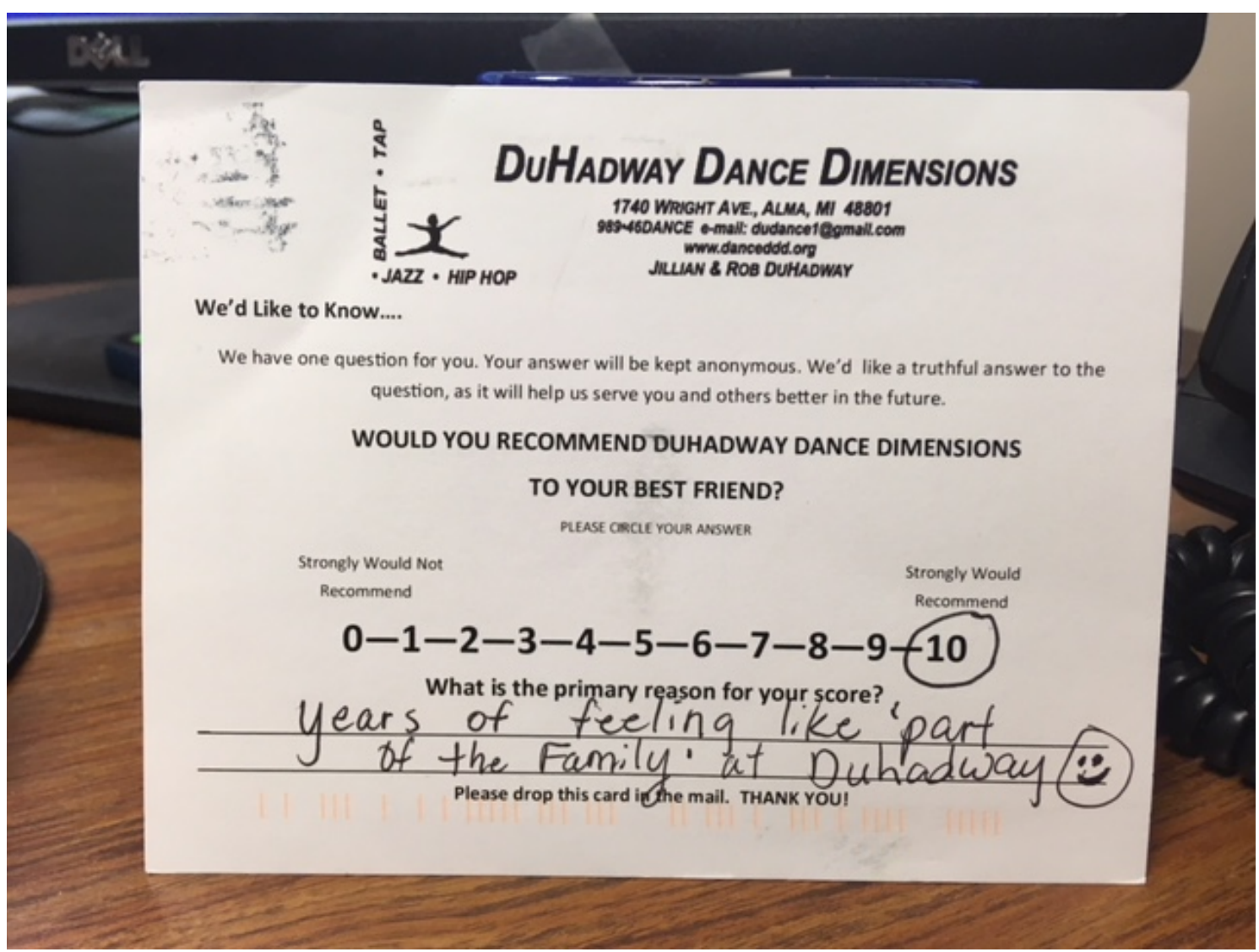




\section{Letter from DuHadways}

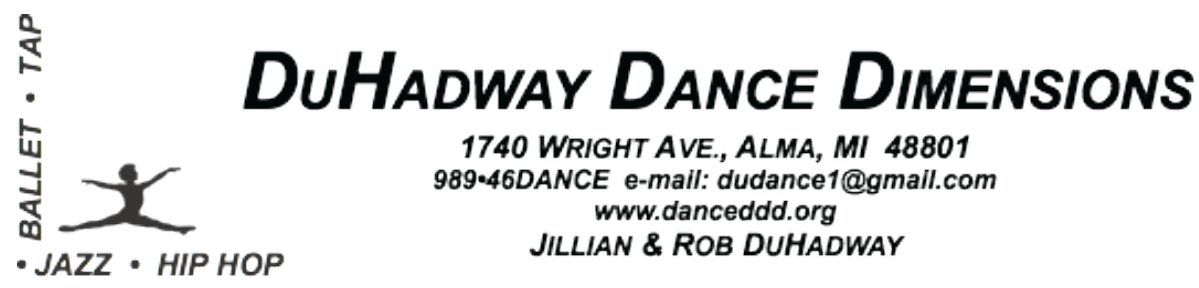

Hello DDD families!

We at DuHadway Dance Dimensions are always looking for ways to improve our service to our dancers and their families. You've received this letter because we'd like to know 'how are we doing?'

We've engaged researchers from the Business Administration department at Alma College to help us with this project. You'll find enclosed a postcard. We are asking you to answer one simple question as to whether you'd recommend us to your best friend and how strongly you feel about that recommendation.

Please feel free to tell us the reason for your response at the bottom of the card.

You'll note the postcard is already stamped. All you need to do is drop it in the mail. By the way, your answer is totally anonymous. We have no way of tracing where responses come from.

Thank you very much for your help with this project. We are here to give the best dance instruction we possibly can and your opinion will help us with that mission.

Thank you so much,

Rob and Jillian DuHadway

DuHadway Dance Dimensions

1740 Wright Ave

Alma, MI 48801

(989) 463-2623 


\section{APPENDIX C}

\section{Scoring and Comments}

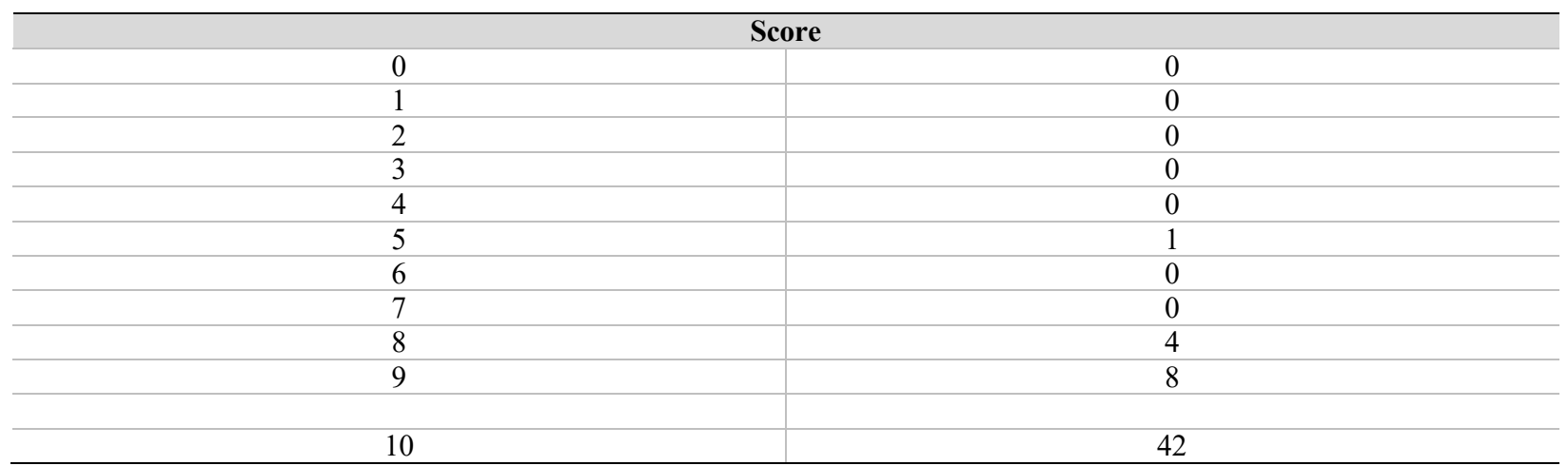

\section{COMMENTS}

\section{Rating 5:}

"My child is younger and in one of the beginning classes, we never get any feedback from the teacher. Should the child move to the next class or stay in current class for some time. I have also witnessed my child not mastering a technique, but the teacher does nothing to correct it."

\section{Rating 8:}

"You guys do a great job! :)"

"It would be a 10 if teachers paid more attention to all kids — not just Elite Team dancers."

"Great dance instructors, but the scheduling isn't great. I didn't get the one day I said would work for my family."

"It has good instructors and good dancers, however the pink room is a little small for 12 dancers."

\section{Rating 9:}

"Excellent guidance and growth opportunities."

"DDD has always offered lots of options for my dancer and been good about scheduling requests. Facilities are nice and instructors are knowledgeable."

"Positives: Strong dance education, community service values, positive atmosphere, various opportunities and levels. Negatives: communication and long range planning could be better. For example, schedule changes, costs, etc."

"Yes for serious dancers."

"I have seen overly harsh treatment of my daughter and a few other students (young students) by one of the staff during class. This has made a few people that I am aware of, consider leaving. Overall studio atmosphere and feeling of family is fantastic."

"The owners are very friendly and helpful." 
"Only reason it's not a 10 is cost $;$; and difficulty getting into tumbling class."

"Friendly, helpful, skilled"

\section{Rating 10:}

"Made us feel welcome from day one. Great with the kids and families! Awesome staff."

"Teacher excellence, creating a positive environment for my daughter"

"On my daughters first day of dance she cried a lot and was scared, but Ms. Jillian was so patient and she absolutely loves how funny her teacher is."

"Best dance school in the area-teaching dance team, opportunities for dancers to grow, and take dance further in their lives."

"My kids love this dance studio!"

"It gives my daughter a positive outlet. Please provide an additional play area for little brothers and sisters. Sometimes older dancers leave cell phone/ valuables laying around. I get worried about theft. Encourage to lock up!"

"Years of feeling like part of the family at DuHadway:-)"

"We love the studio; the ballet program is \#1 and makes the dancers strong."

"Friendly, knowledgeable staff, my kids are happy and excited to go, that makes me happy too."

"Quality instruction and highly organized."

"Nice staff. My child enjoys coming to class."

"DuHadway is family oriented(-)"

"You are very knowledgeable in your teaching and ways of teaching. But also, very caring and generous."

"Smart, wise, talented, 'family’ with outreach”

"Friendly staff and knowledge of dance."

"Wonderful instructors, owners, and families!"

"They have been helpful and welcoming and informative to newbies and the teacher has gotten my dance loving daughter to participate"

"Kids love going to dance! Great studio and teachers!"

"Our daughter enjoys her class. No problems or issues."

"Fantastic stuff! They all go above and beyond for our kids! They treat you like family."

"Feels like family(;)"

"My daughter loves to dance here! The atmosphere and all the staff is amazing! Many more years to come!"

"This studio has always treated me like family. DuHadway is a wonderful dance company." 
"We love DDD!!!"

"Friendly staff and quality instructors who encourage."

"We love the class and our daughter is learning and engaged."

"Great friendly environment. Mr. Rob and Ms. Jillian are great!"

"Friendly environment. Great staff and teachers! I would recommend having bigger windows for parents to view dancers while in class."

"Great teachers work with you on schedule, payment plan."

"Strong leadership and knowledgeable instructors."

"We've had a great experience. Our daughter has learned a lot and had fun along the way."

"Care and consideration for the individual student."

"They're always there for the kids to support, teach, encourage, strengthen, and love them. Amazing people, amazing company. We love you DDD!”

"They treat everyone like family."

"We love the friendly atmosphere and Allie loves her dance teacher. So glad we joined your studio!"

"We enjoy the studio atmosphere, the dance instruction our girls are receiving, and the attention that is paid to my girls in support of other activities they do."

"I tell my friend all the time. You guys make my family feel like family! I love that. We don't feel like just someone paying for dance. You're always there to help and answer questions. Thank you for everything!" 


\section{NOTES}

